\title{
PKM PRODUKSI TEPUNG TAPIOKA MALTODEKSTRIN DAN BIOETANOL BAGI KELOMPOK TANI SINGKONG
}

\author{
Dewi Selvia Fardhyanti ${ }^{1)}$, Ratna Dewi Kusumaningtyas ${ }^{2)}$, Megawati ${ }^{3)}$, Dhoni \\ Hartanto $^{4)}$ \\ Jurusan Teknik Kimia, Fakultas Teknik, Universitas Negeri Semarang, Kampus Sekaran Gunung \\ Pati, Semarang 50229, Indonesia \\ dewiselvia@mail.unnes.ac.id*
}

\begin{abstract}
ABSTRAK
Desa Magelung adalah salah satu desa penghasil ketela pohon di Kecamatan Kaliwungu Barat Kabupaten Kendal. Setelah terbentuknya beberapa Kelompok Tani Singkong (KTS) di desa ini, singkong bisa diproduksi menjadi tepung tapioka. Namun usaha ini masih sangat sederhana dan tersendat-sendat karena teknologi yang digunakan masih sangat sederhana dan bersifat manual. Untuk itu dibutuhkan pengolahan tapioka full otomated dengan modifikasi asam yang memiliki efisiensi tinggi, karena proses produksi memerlukan tenaga kerja yang sedikit, waktu lebih pendek dan menghasilkan tapioka lebih berkualitas (lebih putih, lebih mudah larut dalam air, dan lebih halus). Tepung tapioka termodifikasi asam biasa disebut dengan maltodekstrin yang mempunyai nilai jual jauh lebih tinggi dibandingkan singkong maupun tepung tapioka. Kegiatan pengabdian ini mempunyai beberapa target yaitu (1) ketersediaan peralatan yang sangat dibutuhkan masyarakat untuk diversifikasi produk unggulan yang telah dikembangkan, misalnya mesin penggerak/generator, mesin parut, mesin pompa, dan mesin ayakan, mesin pembuat pakan ternak, dan mesin bioetanol untuk praktik. (2) Pelatihan dan praktik pembuatan tepung tapioka termodifikasi asam, pakan ternak terfermentasi, dan bioetanol. (3) Melalui program diversifikasi produk, singkong dapat menghasilkan produk yang bervariasi dan potensial untuk pengembangan potensi industri olahan rumah tangga, sehingga diharapkan memiliki jiwa enterpreneurship yang meningkat dan bisa mengolah singkong menjadi produk industri rumah tangga yang kreatif dan inovatif. (4) Menghasilkan desain kemasan sehingga menarik konsumen, ditunjang pelaksanaan strategi pemasaran dan promosi yang telah dipilih oleh peserta KTS bersama tim pendamping. (5) Penciptaan struktur organisasi yang bisa memisahkan tugas dan tanggung jawab secara tegas antar masing-masing anggota organisasi. (5) Menjalin pola kemitraan antara KTS dengan Dinas Perdagangan dan Perindustrian Kabupaten Kendal untuk menciptakan iklim usaha yang kondusif, menumbuh kembangkan industri kecil dan menengah di Desa Magelung. (6) Pengemasan produk juga menjadi aspek yang menjadi satu paket konsep produk luaran kami. Luaran yang dihasilkan publikasi di jurnal/prosiding dan media massa, peningkatan omzet mitra, kualitas dan kuantitas produk, keterampilan masyarakat dan produk berupa tepung tapioka termodifikasi asam, pakan ternak terfermentasi, dan bioetanol.
\end{abstract}

Kata kunci: singkong, tepung tapioka, pakan ternak, bioetanol, Magelung

\begin{abstract}
Magelung Village is one of the cassava producing villages in Kaliwungu Barat District, Kendal Regency. After the formation of several Cassava Farmers Groups (KTS) in this village, cassava can be produced into tapioca flour. But this business is still very simple and stagnant because the technology used is still very simple and manual. For this reason, full tapioca processing is required with acid modification that has high efficiency, because the production process requires little labor, shorter time and produce higher quality tapioca (whiter, easier to dissolve in water, and smoother). Modified tapioca flour is commonly called maltodextrin which has a much higher sale value than cassava or tapioca flour. This service activity has several targets, namely (1) availability of equipment that is needed by the community to diversify superior products that have been developed, for example propulsion engines, grated machines, pumping machines, sieve machines, animal feed making machines, and bioethanol machines for practice . (2) Training and practice of making acid modified tapioca flour, fermented animal feed, and bioethanol. (3) Through product diversification programs, cassava can produce varied and potential products for the development of household processed industrial potential, so that it is expected to have an entrepreneurial spirit that is increasing and can process cassava into a creative and innovative
\end{abstract}


home industry product. (4) Producing packaging designs to attract consumers, supported by the implementation of marketing and promotion strategies that have been chosen by the KTS participants with the accompanying team. (5) Creation of an organizational structure that can explicitly separate tasks and responsibilities between each member of the organization. (5) Establishing a partnership pattern between KTS and the Kendal Regency Trade and Industry Office to create a conducive business climate, grow small and medium industries in Magelung Village. (6) Product packaging is also an aspect that is one of our external product concept packages. Outcomes generated by publications in journals / proceedings and mass media, increased partner turnover, product quality and quantity, community skills and products in the form of acid modified tapioca flour, fermented animal feed, and bioethanol

Kata kunci: cassava, tapioca flour, animal feed, bioethanol, Magelung.

\section{PENDAHULUAN}

Ketela pohon di Indonesia menjadi makanan bahan pangan pokok setelah beras dan jagung. Manfaat daun ketela pohon sebagai bahan sayuran memiliki protein cukup tinggi, atau untuk keperluan yang lain seperti bahan obat-obatan. Kayunya bisa digunakan sebagai pagar kebun atau di desa-desa sering digunakan sebagai kayu bakar untuk memasak. Dengan perkembangan teknologi, ketela pohon dijadikan bahan dasar pada industri makanan dan bahan baku industri pakan. Selain itu digunakan pula pada industri obat-obatan. Singkong (cassava) sudah lama dikenal diseluruh dunia yang merupakan bahan pangan yang sering dikonsumsi dan digunakan dalam tatanan pengembangan agribisnis dan agroindustri. Singkong berperan cukup besar dalam mencukupi bahan pangan nasional dan dibutuhkan sebagai bahan baku berbagai industri makanan.

Desa Magelung terletak di kecamatan Kaliwungu Selatan dan berada di bawah kendali pemerintah kabupaten Kendal. Luas wilayah desa sebesar 433.372 Ha dengan jumlah penduduk sebanyak 8.985 jiwa dan kepadatan penduduk sebesar 3.993 jiwa per km2. Desa Magelung berada sejauh $4 \mathrm{~km}$ dari kantor Camat Kaliwungu Selatan dan $1 \mathrm{~km}$ dari kantor Bupati. Desa ini memiliki profil penduduk yang didominasi oleh wanita, dengan perbandingan $1: 3$. Penggunaan lahan di desa Magelung sebanyak 9,47 Ha untuk persawahan, 25,53 Ha untuk bukan persawahan, 190,02 Ha bukan pertanian, dan luas wilayah seluruhnya seluas 225,03 Ha (BPS, 2015). Lahan pertanian bukan sawah yang ada di desa ini seluas $23,49 \mathrm{Ha}$ yang sebagian besar digunakan untuk menanam singkong (BPS, 2015). Produksi singkong di kecamatan Kaliwungu Selatan pada tahun 2015 sebanyak 926,03 ton dan produktivitasnya sebesar 250,28 kuintal per hektar.

Kondisi geografis desa yang berada pada ketinggian tinggi menyebabkan lahan pertanian pada daerah ini sangat subur. Mayoritas mata pencaharian penduduk desa sebagai petani, mengingat potensi sumber daya alam di area lereng gunung ungaran yang cocok sebagai lahan pertanian. Untuk lahan tegal yang kurang mendapat air, para warga pada daerah ini biasanya menanami dengan pohon singkong. Hampir semua warga di desa Magelung ini mempunyai tanaman singkong. Ribuan ketela pohon adalah rumah bagi penduduk Desa 
Magelung, karena ketela pohon tumbuh menyebar diantara rumahrumah penduduk. Ironisnya, secara ekonomis, penduduk desa ini memiliki tingkat ekonomi menengah ke bawah, dengan rata-rata penghasilan setiap kepala keluarga di kisaran Rp $1.000 .000 \quad-\quad \mathrm{Rp}$ 2.000.000.

Menurut Kepala Desa Magelung, Slamet, pada saat panen, singkong yang dihasilkan hanya dijual saja, dengan harga jual cukup rendah. Regulasi tersebut dimaksudkan agar petani sebagai produsen bahan baku dapat membiayai dan tetap melangsungkan usahanya. bahkan jika harga ketela pohon jatuh, maka hanya digunakan untuk pangan ternak. Setelah terbentuknya beberapa Kelompok Tani Singkong (KTS) di desa ini, singkong bisa diproduksi menjadi tepung tapioka. Namun usaha ini masih sangat sederhana dan tersendat-sendat karena teknologi yang digunakan masih sangat sederhana dan bersifat manual. Harga ketela pohon sekarang mencapai Rp 2.000 per $\mathrm{kg}$, ditingkat petani, sedangkan jika sudah didiversifikasi menjadi tepung tapioka harganya meningkat menjadi berkisar antara Rp 6.500 - Rp 7.500 per kg. Tepung tapioka yang termodifikasi asam menjadi produk baru bernama maltodekstrin dengan harga jual jauh lebih tinggi sekitar Rp. 12.000 per $\mathrm{kg}$. Untuk itu dibutuhkan pengolahan tapioka full otomated dengan modifikasi asam yang memiliki efisiensi tinggi, karena proses produksi memerlukan tenaga kerja yang sedikit, waktu lebih pendek dan menghasilkan tapioka lebih berkualitas (lebih putih, lebih mudah larut dalam air, dan lebih halus).
Disamping itu limbah padat (onggok singkong) yang dihasilkan belum dimanfaatkan menjadi produk lain yang bernilai tinggi yaitu menjadi pakan ternak terfermentasi dan limbah kulit singkong dapat dimanfaatkan menjadi bioetanol menjadi bahan bakar.

Mendasarkan uraian di atas, maka permasalahan mitra dapat dibagi menjadi dua, yaitu aspek produksi dan aspek manajemen. Aspek produksi, permasalahan utama adalah tidak adanya diversifikasi produk singkong, pada kelompok tani desa Magelung, selain singkong yang langsung dijual ke konsumen. Sehingga perlu dicari solusi yang tepat. Dalam aspek manajemen, kelompok tani desa Magelung belum mampu mengaplikasikan jiwa kewirausahaannya, sehingga belum memahami bagaimana cara pembuatan tepung tapioka termodifikasi asam, pengolahan limbah padat dan kulitnya, pengemasan, dan pemasarannya serta pengelolaan keuangan untuk home industry, sehingga perlu diberikan pelatihan-pelatihan manajemen.

\section{METODE PELAKSANAAN}

A. Kerangka Pemecahan Masalah

Metode pelaksanaan kegiatan menggunakan pendekatan partisipatif, yaitu pelatihan yang pelaksanaan pembelajarannya dilakukan secara partisipatif antara pelatih dan peserta pelatihan. Prosedur kerja pada pengabdian ini meliputi:

1. Persiapan Pelatihan, meliputi persiapan peserta pelatihan yang terdiri dari 2 kelompok tani mitra yaitu KTS Rukun yang diketuai 
oleh Bapak Ahmad Jazuri dan KTS Sejahtera yang diketuai oleh Bapak Catur dan perwakilan dari Gapoktani yang diketuai oleh bapak Suud Kholil.

2. Persiapan tenaga fasilitator dan instruktur yang terdiri dari dosen dan mahasiswa.

3. Persiapan Sarana Pelatihan.

\section{Pelaksanaan}

Pelatihan, meliputi pelatihan teknis pengolahan produksi tepung tapioka termodifikasi asam, pengolahan onggok singkong menjadi pakan ternak terfermentasi, serta pengolahan kulit singkong menjadi bioetanol. Pelatihan ini meliputi materi proses produksi dan proses packaging. Pelatihan manajemen telah dilaksanakan sebanyak 3 kali, meliputi manajemen pemasaran, manajemen keuangan dan manajemen kewirausahaan.

5. Pemantauan dan Evaluasi Pelatihan, tahap ini telah dilakukan secara periodik sehingga keberlangsungan usaha kelompok tani desa Magelung dapat berkesinambungan.

Berdasarkan prosedur kerja di atas, maka kegiatan dalam pengabdian ini dilakukan sebagai berikut:

\section{a.Tahap 1}

Luaran tahap ini adalah meningkatnya kemampuan teknologi produksi, kelompok tani desa Magelung dapat mengolah singkong menjadi tepung tapioka termodifikasi asam.

Terdapat 2 kegiatan yaitu:

1) Pelatihan produksi
Pelatihan produksi meliputi praktek pembuatan tepung tapioka termodifikasi asam. Hasil dari pelatihan ini berupa produk tepung tapioka dan limbah padatnya yang berupa onggok singkong menjadi pakan ternak terfermentasi serta kulit singkong menjadi bioetanol.

2) Uji kualitas tepung tapioka yang memenuhi standar BPOM dan uji performa bioetanol yang memenuhi syarat menjadi bahan bakar.

\section{b. Tahap 2}

Luaran dalam tahap ini adalah kemampuan manajerial dari kelompok tani desa Magelung, Pelatihan Manajemen meliputi:

Pelatihan manajemen pemasaran meliputi materi marketing mix yang tepat untuk pemasaran produk, termasuk sistem pengemasan (packaging) yang menarik serta pengelolaan administrasi untuk perolehan hak cipta pada produk.

Pelatihan manajemen keuangan meliputi materi pengelolaan usaha dan penyusunan laporan keuangan secara sederhana.

\section{c. Tahap 3}

Tujuan tahap ini adalah memberikan jaminan atau kepercayaan ke publik bahwa keberlangsungan usaha pada kelompok tani desa Magelung tidak akan berhenti produksi. Pada tahap ini dilakukan perolehan ijin produk dari Departemen setempat serta dilakukan evaluasi keberlangsungan usaha mitra, dan evaluasi pengabdian masyarakat, melalui peninjauan secara periodik ke setiap kelompok tani.

B. Realisasi Pemecahan 
Kegiatan pengabdian masyarakat ini dilakukan dalam beberapa tahap yaitu tahap observasi, perijinan, sosialisasi dan tahap pelaksanaan.

1. Tahap Observasi (tanggal 2 s.d. 6 Juli 2018)

Telah dilakukan observasi dan pendataan jumlah KTS desa Magelung Kecamatan Kaliwungu Selatan Kabupaten Kendal yang potensial untuk dilibatkan dalam program pengabdian kepada masyarakat ini. Tahap ini adalah merupakan kegiatan awal dengan menjaring permasalahan yang ada di masyarakat. Pada tahap ini KTS menghendaki pemberian ketrampilan produksi tepung tapioka termodifikasi asam (maltodekstrin), pengolahan onggok singkong menjadi pakan ternak terfermentasi, serta pengolahan kulit singkong menjadi bioetanol.

\section{Tahap Perijinan} (tanggal 10 Juli 2018)

Tim pengabdian masyarakat mengadakan pertemuan dengan Lurah desa Magelung meminta ijin untuk memberikan ketrampilan produksi tepung tapioka termodifikasi asam (maltodekstrin), pengolahan onggok singkong menjadi pakan ternak terfermentasi, serta pengolahan kulit singkong menjadi bioetanol kepada KTS desa Magelung Kecamatan Kaliwungu Selatan Kabupaten Kendal. Pada tahap ini Tim pengabdian masyarakat juga menjelaskan tentang rincian kegiatan yang akan dilakukan.

3. Tahap Sosialisasi (tanggal 28 Juli 2018)

Sosialisasi ini dilakukan untuk memberi wawasan yang bersifat teoritis dan praktis tentang materi pengabdian yaitu pemberian ketrampilan produksi tepung tapioka termodifikasi asam (maltodekstrin), pengolahan onggok singkong menjadi pakan ternak terfermentasi, serta pengolahan kulit singkong menjadi bioetanol kepada KTS desa Magelung Kecamatan Kaliwungu Selatan Kabupaten Kendal. Tatap muka dan wawancara telah dilakukan seputar manfaat singkong dan teknik ketrampilan produksi tepung tapioka termodifikasi asam (maltodekstrin), pakan ternak terfermentasi dan bioetanol juga kepada KTS desa Magelung Kecamatan Kaliwungu Selatan Kabupaten Kendal.

4. Tahap Pelaksanaan (tanggal 11 s.d 16 Agustus 2018)

Pada tahap ini dilakukan pelatihan teknik pengolahan produksi tepung tapioka termodifikasi asam, pengolahan onggok singkong menjadi pakan ternak terfermentasi, serta pengolahan kulit singkong menjadi bioetanol kepada KTS desa Magelung Kecamatan Kaliwungu Selatan Kabupaten Kendal bersama tim pengabdian masyarakat.

5. Tahap Evaluasi (tanggal 15 s.d 30 September 2017)

Pada tahap ini dilakukan monitoring kegiatan yang dilakukan oleh KTS desa Magelung Kecamatan Kaliwungu Selatan Kabupaten Kendal. Pelaksanaan monitoring ini dilakukan untuk mengetahui sejauh mana peran serta KTS desa Magelung Kecamatan Kaliwungu Selatan Kabupaten Kendal terhadap kegiatan yang dilakukan di wilayahnya.

Evaluasi dilakukan terhadap keseluruhan pelaksanaan program, dengan melakukan pengamatan terhadap hasil produksi tepung 
tapioka termodifikasi asam (maltodekstrin), pakan ternak terfermentasi, dan bioetanol. Pada tahap ini juga dapat digunakan untuk mengetahui minat KTS desa Magelung Kecamatan Kaliwungu Selatan Kabupaten Kendal untuk melakukan pelatihan teknik produksi tepung tapioka termodifikasi asam (maltodekstrin), pengolahan onggok singkong menjadi pakan ternak terfermentasi, serta pengolahan kulit singkong menjadi bioetanol. Pada kegiatan ini juga akan dievaluasi

\section{HASIL DAN PEMBAHASAN}

Evaluasi pelatihan ini dilakukan dari dua segi yaitu evaluasi terhadap proses pelatihan dan evaluasi terhadap hasil pelatihan. Evaluasi terhadap proses dan hasil pelatihan mendapatkan hasil sebagai berikut :

\section{A. Analisis Hasil Evaluasi}

Evaluasi pelatihan ini dilakukan dari dua segi yaitu evaluasi terhadap proses pelatihan dan evaluasi terhadap hasil pelatihan. Evaluasi terhadap proses dan hasil pelatihan mendapatkan hasil sebagai berikut :

\section{Evaluasi terhadap Proses Pelatihan}

Sebelum kegiatan sosialisasi, dilakukan observasi untuk mengetahui tingkat pengetahuan yang dimiliki oleh para peserta penyuluhan tentang manfaat singkong dan teknik produksi tepung tapioka termodifikasi asam (maltodekstrin), pengolahan onggok singkong menjadi pakan ternak terfermentasi, serta pengolahan kulit singkong menjadi bioetanol. Metode yang dilakukan adalah tanya jawab. Hasil yang diperoleh sebagai berikut :

Hampir $100 \%$ peserta belum pernah mengetahui manfaat singkong dan belum pernah membuat tepung tapioka kelebihan dan kekurangan, evaluasi Break Event Point (BEP) serta mempertimbangkan masukanmasukan dari peserta pelatihan yang bersifat konstruktif.

6. Tahap Penyusunan Laporan Kegiatan

Setelah selesainya kegiatan pengabdian kepada masyarakat ini, maka disusunlah laporan kegiatan sebagai pertanggungjawaban atas tugas yang telah dilaksanakan.

termodifikasi asam (maltodekstrin), pengolahan onggok singkong menjadi pakan ternak terfermentasi, serta pengolahan kulit singkong menjadi bioetanol sebagai produk diversifikasi singkong.

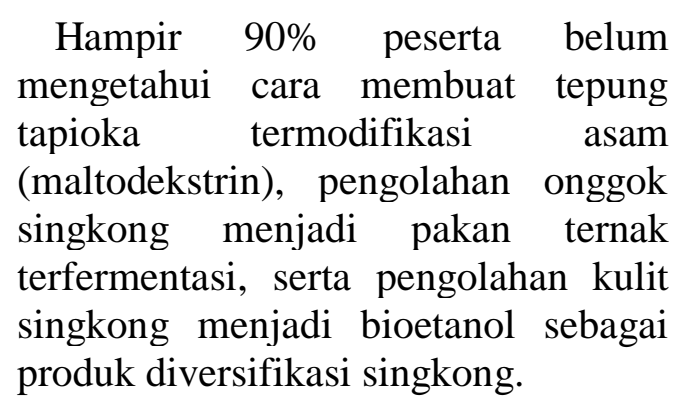

Lebih dari $85 \%$ peserta mempunyai keinginan untuk mencoba melakukan pembuatan tepung tapioka termodifikasi asam (maltodekstrin), pengolahan onggok singkong menjadi pakan ternak terfermentasi, serta pengolahan kulit singkong menjadi bioetanol sebagai produk diversifikasi singkong.

Sosialisasi yang kedua dilakukan dengan memberikan penyuluhan tentang manfaat singkong dan pemberian ketrampilan teknik pembuatan tepung tapioka termodifikasi asam (maltodekstrin), pengolahan onggok singkong menjadi pakan ternak terfermentasi, serta pengolahan kulit singkong menjadi bioetanol sebagai produk diversifikasi 
singkong kepada masyarakat. Penyampaian materi penyuluhan dilakukan secara terpadu yaitu metode ceramah, tanya jawab dan diskusi. Setelah kegiatan penyampaian materi dilaksanakan, diadakan evaluasi untuk mengetahui seberapa jauh peserta menyerap materi yang disajikan tim pengabdian. Berdasarkan hasil evaluasi lisan yang dilakukan menunjukkan bahwa para peserta sangat antusias sekali untuk mengolah singkong menjadi tepung tapioka termodifikasi asam (maltodekstrin) sebagai produk diversifikasi singkong.

Kegiatan selanjutnya dilakukan uji coba membuat tepung tapioka termodifikasi asam (maltodekstrin), pengolahan onggok singkong menjadi pakan ternak terfermentasi, serta pengolahan kulit singkong menjadi bioetanol sebagai produk diversifikasi singkong. Pada pelaksanaan uji coba ini para peserta menunjukkan semangat yang tinggi dan sikap yang serius dalam mengikuti kegiatan ini. Hal ini ditunjukkan dengan banyaknya pertanyaan yang muncul dari peserta pelatihan.

\section{Evaluasi terhadap Hasil Pelatihan}

Evaluasi ini dilakukan setelah program pemberian ketrampilan teknik produksi tepung tapioka termodifikasi asam (maltodekstrin), pengolahan onggok singkong menjadi pakan ternak terfermentasi, serta pengolahan kulit singkong menjadi bioetanol sebagai produk diversifikasi singkong. Kegiatan ini dilakukan bersama antara para peserta penyuluhan dengan tim pengabdian masyarakat. Alokasi waktu yang diperlukan untuk program ini lebih besar daripada untuk program sosialisasi. Hal ini dimaksudkan agar para peserta betul-betul dapat membuat tepung tapioka termodifikasi asam (maltodekstrin), pengolahan onggok singkong menjadi pakan ternak terfermentasi, serta pengolahan kulit singkong menjadi bioetanol sebagai produk diversifikasi singkong. Evaluasi dilakukan pada hasil kerja para peserta penyuluhan baik secara individual maupun secara kelompok. Berdasarkan hasil evaluasi tim pengabdian, dapat dilihat bahwa para peserta sudah dapat mengolah singkong menjadi tepung tapioka termodifikasi asam (maltodekstrin), pengolahan onggok singkong menjadi pakan ternak terfermentasi, serta pengolahan kulit singkong menjadi bioetanol sebagai produk diversifikasi singkong.

B. Faktor Pendorong dan Penghambat

Kegiatan pengabdian ini keberhasilannya dipengaruhi oleh adanya faktor pendorong dan penghambat yaitu :

\section{Faktor Pendorong}

Faktor pendorong dari kegiatan ini adalah sikap antusias dan motivasi dari KTS desa Magelung Kecamatan Kaliwungu Selatan Kabupaten Kendal. Teknologi pembuatan tepung tapioka termodifikasi asam (maltodekstrin), pengolahan onggok singkong menjadi pakan ternak terfermentasi, serta pengolahan kulit singkong menjadi bioetanol sebagai produk diversifikasi singkong mudah diaplikasikan oleh masyarakat. Mereka juga meminta kepada tim pengabdian agar kegiatan ini ditindak lanjuti.

\section{Faktor Penghambat}

Faktor penghambat relatif tidak ada, hanya pada pengolahan tepung tapioka termodifikasi asam (maltodekstrin), pengolahan onggok singkong menjadi 
pakan ternak terfermentasi, serta pengolahan kulit singkong menjadi bioetanol sebagai produk diversifikasi singkong kepada masyarakat perlu diperhatikan cara penggunaan bahan kimianya.

\section{KESIMPULAN}

Kelompok Tani Singkong desa Magelung Kecamatan Kaliwungu Selatan Kabupaten Kendal potensial untuk dilibatkan dalam program pengabdian kepada masyarakat ini dapat melakukan teknik produksi tepung tapioka termodifikasi asam (maltodekstrin), pengolahan onggok singkong menjadi pakan ternak terfermentasi, serta pengolahan kulit singkong menjadi bioetanol sebagai produk diversifikasi singkong dengan baik.

\section{REFERENSI}

BPS, 2016.

Ciptasari, R. 2015. Pembuatan Etanol dari Limbah Kulit Jeruk Bali: Hidrolisis Menggunakan Selulase dan Fermentasi dengan Yeast. Program Studi Teknik Kimia, Fakultas Teknik, Universitas Negeri Semarang.

Direktorat Jenderal Pengolahan dan Pemasaran Hasil Pertanian, Kementerian Pertanian. 2011. Pedoman/Petunjuk Tekins Pengolahan Hasil Aneka Umbi.

Soegihardjo, O., dan Aninditya. 2005. Perancangan Mesin Pembuat Tepung Tapioka. Jurnal Teknik Mesin, Vol. 7 No.1, 22-27.

Waktya Jati, P. 2006. Pengaruh Waktu Hidrolisis dan Konsentrasi $\mathrm{HCl}$ terhadap Nilai Dextrose Equivalent (DE) dan Karakterisasi Mutu Pati Termodifikasi dari Pati Tapioka dengan Metode Hidrolisis
Asam, Departemen Teknologi

Industri Pertanian, Fakultas

Teknologi Pertanian, Fakultas

Teknologi Pertanian, Institut Pertanian Bogor.

www.jzdafo.com diakses pada 9-62017 